\title{
EDITORIAL
}

\section{Perspectives on the interface between normal and atypical development}

In a recent article, it was noted that many of the ideas that are central to our current organismic models of development had their roots in the very beginnings of Western philosophy and in embryology (see Cicchetti, 1990a). For example, one can see that the contemporary notion of the role of the integration of multiple domains of behavior for the harmonious functioning of the individual (cf. Cicchetti, 1990b; Sroufe \& Fleeson, 1986) was anticipated by the Platonic conception of the triune character of the soul. Moreover, Plato's conceptualization of the dominance of reason (a higher function in his view) over passion (a lower function) is an early illustration of the idea of hierarchically integrated domains of functioning.

Likewise, Aristotle was one of the first authors to contend that individuation, differentiation, and self-actualization were the characteristic aspects of developmental transformations (cf. Kaplan, 1967). Additionally, Aristotle believed in the dynamic relationship between the individual and the environment, stressed that behavior was multiply determined and that different levels of behavioral organization existed within humans, and argued that principles of behavior should be viewed in terms of the organization among parts and wholes. Despite the fact that these early philosophers did not relate their ideas to psychopathological conditions, their work had a

I would like to thank Sheree Toth for her comments and Donna Bowman for typing this manuscript. profound influence on developmentalists of diverse persuasions.

Similarly, theory and research conducted in embryology have made rich contributions to formulating and advancing developmental theory (Cairns, 1983; Gottlieb, 1983; Kuo, 1967; Sameroff, 1983; Waddington, 1957; Weiss, 1969). It was from their empirical efforts to unravel the mysteries of normal embryological functioning that early embryologists derived the principles of differentiation, of a dynamically active organism, and of a hierarchically integrated system, three of the cornerstone beliefs of the Western philosophers. These advances in our knowledge about normal embryological development were later used in the investigation of the processes of abnormal development within the contemporary fields of the neurosciences, embryology, and experimental psychopathology (Cicchetti, 1990a; Goldstein, 1940; Shakow, 1968; Weiss, 1969).

Within the neurosciences, for example, progress in molecular cell biology has stemmed from developmental research on normal and abnormal variations in cells (e.g., research on the development of cell specificity, cancer, immunity, etc. [see Darnell, Lodish, \& Baltimore, 1986]). Likewise, research on the development of the central nervous system has led to an increased understanding of the processes underlying the diversity and complexity of the mature nervous system (e.g., what processes dictate which genes are expressed in particular cell types and what regulates the timing of the genetic expression? [see No- 
wakowski, 1987; Watson, Hopkins, Roberts et al., 1987]). Finally, molecular neurobiological research on developmental disorders of the nervous system (e.g., critical periods in brain development, genetic mutations, disorders of neural tube formation, disorders of neural migration, disorders of myelination, disorders of synapse formation, etc.) has augmented our knowledge of basic molecular neurobiology (Ciaranello, Wong, \& Rubenstein, 1990; Coyle, Oster-Granite, \& Gearhart, 1986; Friede, 1975; Huttenlocher, 1979; Rakic, 1975; Sidman \& Rakic, 1973, 1982; Zimmerman, Bilaniuk, \& Grossman, 1983).

Throughout history, then, prominent theoreticians, researchers, and clinicians have adopted the premise that knowledge about normal and abnormal development enriches each area. Embryologists, neuroscientists, and psychiatrists, as well as clinical, developmental, and experimental psychologists, have emphasized that research on normal and atypical populations must proceed hand in hand in order to formulate a truly integrative theory of development that can account for normal and deviant forms of ontogenesis (cf. Sroufe, this issue).

In this tradition, Werner (1948) reasoned that a "whole series of mental diseases are important to developmental psychology in that they represent the regression, the dissolution, of the higher mental processes, or inhibitions of the genetically advanced levels" (p. 23) (see Jackson, 1884/1958, for a similar argument based on studies of patients with neurological conditions). Furthermore, Freud (see, e.g., $1940 \mathrm{a} / 1955,1940 \mathrm{~b} / 1955$ ) stressed the central importance of the irrational, thereby underscoring the close connection between the normal and the abnormal.

Freud's ideas regarding a normality/abnormality continuum have not only permeated the fields of psychology and psychiatry, but also have influenced theoreticians in developmental psychopathology (see, e.g., Cicchetti, 1984b; Plomin, Rende, \& Rutter, in press; Rende \& Plomin, this issue; Rutter, 1986; Rutter \& Garmezy, 1983; Sroufe, 1989; Sroufe \& Rutter, 1984). In fact, one of the basic tenets of a developmental psychopathology framework is that the application of knowledge of normal development can enhance our understanding of risk and psychopathological conditions, while, reciprocally, the examination of abnormality can elucidate our understanding of normal development (Breslin \& Weinberger, this issue; Cicchetti, 1984b; Cicchetti \& Toth, in press; Rutter, 1986; Sroufe, this issue).

Unfortunately, despite the fact that developmental psychopathologists adhere to the belief that normal and abnormal developmental processes must be examined concurrently, most contemporary theory and research in developmental psychopathology has focused on the contributions that normal development can make to advancing our knowledge of psychopathology. For example, research conducted with normal infants and children has resulted in major advances in our comprehension of the developmental organization of autistic children (Dawson, 1989; Frith, 1989). Specifically, much of the progress in unraveling the attentional, neurobiological, cognitive, representational, socioemotional, and social-cognitive puzzles of autism is directly attributable to concomitant progress related to the normal development of these domains (see, e.g., Baron-Cohen, Leslie, \& Frith, 1985; Dawson \& Lewy, 1989; Mundy \& Sigman, 1989). Indeed, as Cicchetti (1984b, 1990a) stated, before developmental psychopathology could become a distinct discipline, the science of normal development needed to mature. The proliferation of knowledge about psychological and biological development that has occurred during the past several decades has enabled developmental psychopathologists to make compelling progress in unraveling the etiology, course, and sequelae of mental disorders (see, e.g., Benes, in press; Cicchetti, 1984a, in press; Cicchetti \& Aber, 1986; Cicchetti \& Schneider-Rosen, 1986; Davidson, in press; Dawson, in press; Pennington \& Ozonoff, in press; Rolf, Masten, Cicchetti, Nuechterlein, \& Weintraub, 1990; Sameroff \& Emde, 1989; Sigman, 1989; Sroufe, 1989). 
Curiously, given the contributions that the study of psychopathological, atypical, and extreme conditions have made to theory development and refinement in other disciplines (e.g., mathematical singularities, visual illusions, visual agnosias, biological clocks, brain injuries), until recently there has been less recognition that the investigation of risk and psychopathological conditions can affirm, expand, and/or challenge extant developmental theory. Even though caveats and limitations clearly must be considered before generalizing from findings on atypical populations to theories of normal development (Cicchetti \& Beeghly, 1990; Dawson, in press), nonetheless, as "experiments of nature," research into risk, atypical, and psychopathological populations can make significant contributions to our understanding of normal ontogenesis.

In fact, recent studies on atypical and psychopathological populations have enhanced our knowledge of a number of critical issues in normal developmental theory, including: (1) the relation among emotion, cognition, and biology (Cicchetti \& Schneider-Rosen, 1984; Davidson, in press; Dawson, in press); (2) the development of emotion regulation (Cicchetti, Ganiban, \& Barnett, in press); (3) the nature of sensitive periods (Curtiss, 1977; Newport, 1990); (4) the contribution of socioemotional factors to language development (Beeghly, Bretherton, \& Mervis, 1986; Cos-

\section{Mt. Hope Family Center}

University of Rochester

\section{References}

Baron-Cohen, S., Leslie, A., \& Frith, U. (1985). Does the autistic child have a "theory of mind?" Cognition, 21, 37-46.

Beeghly, M., Bretherton, I., \& Mervis, C. B. (1986). Mothers' internal state labelling to toddlers. British Journal of Developmental Psychology, 4, 247261.

Belsky, J., \& Vondra, J. (1989). Lessons from child abuse: The determinants of parenting. In D. Cicchetti \& V. Carlson (Eds.), Child maltreatment: Research and theory on the causes and consequences of child abuse and neglect (pp. 153-202). New York: Cambridge University Press.

Benes, F. (in press). Toward a neurodevelopmental understanding of schizophrenia and other psychi- ter, Gersten, Beeghly, \& Cicchetti, 1989; Gersten, Coster, Schneider-Rosen, Carlson, \& Cicchetti, 1986); (5) the development of the self (Cicchetti, Beeghly, Carlson, \& Toth, 1990; Dawson, in press; Hobson, 1990; Schneider-Rosen \& Cicchetti, in press; Westen, in press); (6) the determinants of parenting (Belsky \& Vondra, 1989); (7) the formation and dissolution of relationships (Crittenden \& Ainsworth, 1989); (8) the relative contributions of maturational and developmental factors to phenotypic change (Cicchetti \& Beeghly, 1990; Newport, 1990); (9) the universality of stages, sequences, and structures, rate of developmental change, and mechanisms underlying rules of developmental transformation (Cicchetti \& Pogge-Hesse, 1982; Hodapp, Burack, \& Zigler, 1990); and (10) the relation between biological and psychological processes (Weinberger, 1987).

As developmentalists, the contributors to this special issue all have a firm knowledge base in normal developmental principles and acknowledge the reciprocal interrelations between normal and abnormal ontogenesis. Additionally, however, all authors were asked to explore how research in psychopathology has enhanced theory that originated from normative populations. The resulting collection of articles are, in many ways, initial and thought-provoking inquiries into the heretofore minimized half of the normal-abnormal equation.

Dante Cicchetti Editor

atric disorders. In D. Cicchetti \& S. Toth (Eds.), Rochester Symposium on Developmental Psychopathology (Vol. 3). Rochester, NY: University of Rochester Press.

Cairns, R. B. (1983). The emergence of developmental psychology. In P. Mussen (Ed.), Handbook of child psychology (Vol. 1, pp. 41-102). New York: wiley.

Ciaranello, R., Wong, D., \& Rubenstein, J. (1990). Molecular neurobiology and disorders of brain development. In S. Deutsch, A. Weizman, \& R. Weizman (Eds.), Application of basic neuroscience to child psychiatry (pp. 9-32). New York: Plenum.

Cicchetti, D. (1984a). Developmental psychopathology. Child Development, 55 [Special Issue]. 
Cicchetti, D. (1984b). The emergence of developmental psychopathology. Child Development, 55, $1-7$.

Cicchetti, D. (1990a). A historical perspective on the discipline of developmental psychopathology. In J. Rolf, A. Masten, D. Cicchetti, K. Nuechterlein, \& S. Weintraub (Eds.), Risk and protective factors in the development of psychopathology (pp. 2-28). New York: Cambridge University Press.

Cicchetti, D. (1990b). The organization and coherence of socioemotional, cognitive, and representational development: Illustrations through a developmental psychopathology perspective on Down syndrome and child maltreatment. In R. Thompson (Ed.), Nebraska Symposium on Motivation. Vol. 36. Socioemotional development (pp. 259-366). Lincoln: University of Nebraska Press.

Cicchetti, D. (in press). Developmental psychopathology and the prevention of serious mental disorders: Overdue detente and illustrations through the affective disorders. In P. Muehrer (Ed.), Conceptual research models for prevention of mental disorders. Rockville, MD: NIMH.

Cicchetti, D., \& Aber, J. L. (1986). Early precursors to later depression: An organizational perspective. In L. Lipsitt \& C. Rovee-Collier (Eds.), Advances in infancy (Vol. 4, pp. 87-137). Norwood, NJ: Ablex.

Cicchetti, D., \& Beeghly, M. (Eds.) (1990). Children with Down syndrome: $A$ developmental perspective. New York: Cambridge University Press.

Cicchetti, D., Beeghly, M., Carlson, V., \& Toth, S. (1990). The emergence of the self in atypical populations. In D. Cicchetti \& M. Beeghly (Eds.), The self in transition: Infancy to childhood (pp. 309344). Chicago: University of Chicago Press.

Cicchetti, D., Ganiban, J., \& Barnett, D. (in press). Contributions from the study of high risk populations to understanding the development of emotion regulation. In K. Dodge \& J. Garber (Eds.), The development of emotion regulation. New York: Cambridge University Press.

Cicchetti, D., \& Pogge-Hesse, P. (1982). Possible contributions of the study of organically retarded persons to developmental theory. In E. Zigler \& D. Balla (Eds.), Mental retardation: The developmental-difference controversy (pp. 277318). Hillsdale, NJ: Erlbaum.

Cicchetti, D., \& Schneider-Rosen, K. (1984). Theoretical and empirical considerations in the investigation of the relationship between affect and cognition in atypical populations of infants: Contributions to the formulation of an integrative theory of development. In C. Izard, J. Kagan, \& R. Zajonc (Eds.), Emotions, cognition and behavior (pp. 366-406). New York: Cambridge University Press.

Cicchetti, D., \& Schneider-Rosen, K. (1986). An organizational approach to childhood depression. In M. Rutter, C. Izard, \& P. Read (Eds.), Depression in young people: Clinical and developmental perspectives (pp. 71-137). New York: Guilford.

Cicchetti, D., \& Toth, S. (in press). The making of a developmental psychopathologist. In J. Cantor, C. Spiker, \& L. Lipsitt (Eds.), Child behavior and development: Training for diversity. Norwood, NJ: Ablex.

Coster, W. J., Gersten, M. S., Beeghly, M., \& Cic- chetti, D. (1989). Communicative functioning in maltreated toddlers. Developmental Psychology, $25,1020-1029$.

Coyle, J., Oster-Granite, M., \& Gearhart, J. (1986). The neurobiologic consequences of Down syndrome. Brain Research Bulletin, 16, 773-787.

Crittenden, P. M., \& Ainsworth, M. (1989). Attachment and child abuse. In D. Cicchetti \& V. Carlson (Eds.), Child maltreatment: Research and theory on the causes and consequences of child abuse and neglect (pp. 432-463). New York: Cambridge University Press.

Curtiss, S. (1977). Genie: A psycholinguistic study of a modern-day "wild child." New York: Academic.

Darnell, J., Lodish, H., \& Baltimore, D. (1986). Molecular cell biology. New York: W. H. Freeman.

Davidson, R. (in press). Cerebral asymmetry and affective disorders: A developmental perspective. In D. Cicchetti \& S. Toth, (Eds.), Rochester Symposium on Developmental Psychopathology. Vol. 2. Internalizing and externalizing expressions of dysfunction. Hillsdale, $\mathrm{NJ}$ : Erlbaum.

Dawson, G. (1989). Autism. New York: Guilford.

Dawson, G. (in press). A psychobiological perspective on the early socioemotional development of children with autism. In D. Cicchetti \& S. Toth (Eds.), Rochester Symposium on Developmental Psychopathology (Vol. 3). Rochester, NY: University of Rochester Press.

Dawson, G., \& Lewy, A. (1989). Reciprocal subcortical-cortical influences in autism: The role of attentional mechanisms. In G. Dawson (Ed.), Autism (pp. 144-173). New York: Guilford.

Freud, S. (1940a/1955). An outline of psychoanalysis. In J. Strachey (Ed.), The standard edition of the complete works of Sigmund Freud (Vol. 23). London: Hogarth.

Freud, S. (1940b/1955). Splitting of the ego in the process of defense. In J. Strachey (Ed.), The standard edition of the complete works of Sigmund Freud (Vol. 23). London: Hogarth.

Friede, R. L. (1975). Developmental neuropathology. New York: Springer-Verlag.

Frith, U. (1989). Autism: Explaining the enigma. Cambridge, MA: Basil Blackwell.

Gersten, M., Coster, W., Schneider-Rosen, K., Carlson, V., \& Cicchetti, D. (1986). The socioemotional bases of communicative functioning: Quality of attachment, language development, and early maltreatment. In M. E. Lamb, A. L. Brown, \& B. Rogoff (Eds.), Advances in developmental psychology (Vol. 4, pp. 105-151). Hillsdale, NJ: Erlbaum.

Goldstein, K. (1940). Human nature in the light of psychopathology. Cambridge, MA: Harvard University Press.

Gottlieb, G. (1983). The psychobiological approach to developmental issues. In P. Mussen (Ed.), Handbook of child psychology (pp. 1-26). New York: Wiley.

Hobson, P. (1990). On the origins of self, and the case of autism. Development and Psychopathology, 2, 163-182.

Hodapp, R., Burack, J., \& Zigler, E. (1990). Summing up and going forward: New directions in the developmental approach to mental retardation. In R. Hodapp, J. Burack, \& E. Zigler (Eds.), Issues in the developmental approach to mental retarda- 
tion (pp. 294-312). New York: Cambridge University Press.

Huttenlocher, R. P. (1979). Synaptic density in human frontal cortex-developmental changes and effects of aging. Brain Research, 163, 195-205.

Jackson, H. J. (1884/1958). Evolution and dissolution of the nervous system. In J. Taylor (Ed.), The selected writings of John Hughlings Jackson (Vol. 2). New York: Basic Books. (From the Crooniam Lectures)

Kaplan, B. (1967). Meditations on genesis. Human Development, 10, 65-87.

Kuo, Z. Y. (1967). The dynamics of behavioral development. New York: Random House. (Reprinted in 1976 by Plenum Press)

Mundy, P., \& Sigman, M. (1989). The theoretical implications of joint-attention deficits in autism. Development and Psychopathology, I, 173-183.

Newport, E. L. (1990). Maturational constraints on language learning. Cognitive Science, 14, 11-28.

Nowakowski, R. S. (1987). Basic concepts of CNS development. Child Development, 58, 568-595.

Pennington, B., \& Ozonoff, S. (in press). A neuroscientific perspective on continuity and discontinuity in developmental psychopathology. In D. Cicchetti \& S. Toth (Eds.), Rochester Symposium on Developmental Psychopathology (Vol. 3). Rochester, NY: University of Rochester Press.

Plomin, R., Rende, R., \& Rutter, M. (in press). Quantitative genetics and developmental psychopathology. In D. Cicchetti \& S. Toth (Eds.), Rochester Symposium on Developmental Psychopathology. Vol. 2: Internalizing and externalizing expressions of dysfunction. Hillsdale, NJ: Erlbaum.

Rakic, P. (1975). Cell migration and neuronal ectopias in the brain. Birth Defects: Original Article Series, $11(7), 95-129$.

Rolf, J., Masten, A., Cicchetti, D., Nuechterlein, K., \& Weintraub, S. (Eds.) (1990). Risk and protective factors in the development of psychopathology. New York: Cambridge University Press.

Rutter, M. (1986). Child psychiatry: The interface between clinical and developmental research. Psychological Medicine, 16, 151-160.

Rutter, M., \& Garmezy, N. (1983). Developmental psychopathology. In P. Mussen (Ed.), Handbook of child psychology (pp. 775-991). New York: Wiley.

Sameroff, A. J. (1983). Developmental systems: Contexts and evolution. In P. Mussen (Ed.), Handbook of child psychology (Vol. 1, pp. 237-294). New York: Wiley.

Sameroff, A. J., \& Emde, R. (Eds.) (1989). Relationships and disturbances in early childhood: $A$ developmental approach. New York: Basic Books.

Schneider-Rosen, K., \& Cicchetti, D. (in press). Early self-knowledge and emotional development: Visual self-recognition and affective reactions to mirror self-images. Developmental Psychology.

Shakow, D. (1968). Contributions from schizophrenia to the understanding of normal psychological function. In M. Simmel (Ed.), The reach of mind: Essays in memory of Kurt Goldstein. New York: Springer.

Sidman, R. L., \& Rakic, P. (1973). Neuronal migration with special reference to developing human brain: A review. Brain Research, 62, 1-35.

Sidman, R. L., \& Rakic, P. (1982). Development of the human central nervous system. In W. Haymaker \& R. D. Adams (Eds.), Histology and histopathology of the nervous system (pp. 3-145). Springfield, IL: Thomas.

Sigman, M. (1989). The application of developmental knowledge to a clinical problem: The study of childhood autism. In D. Cicchetti, (Ed.), Rochester Symposium on Developmental Psychopathology. Vol. 1. The emergence of a discipline (pp. 165-188). Hillsdale, NJ: Erlbaum.

Sroufe, L. A. (1989). Pathways to adaptation and maladaptation: Psychopathology as developmental deviation. In D. Cicchetti (Ed.), Rochester Symposium on Developmental Psychopathology, Vol. 1. The emergence of a discipline (pp. 13-40). Hillsdale, NJ: Erlbaum.

Sroufe, L. A., \& Fleeson, J. (1986). Attachment and the construction of relationships. In W. Hartup \& Z. Rubin (Eds.), Relationships and development. Hillsdale, NJ: Er!baum.

Sroufe, L. A., \& Rutter, M. (1984). The domain of developmental psychopathology. Child Development, 55, 173-189.

Waddington, C. H. (1957). The strategy of the genes. London: Allen \& Unwin.

Watson, J., Hopkins, N., Roberts, J., et al. (1987). Molecular biology of the gene (4th ed.). Menlo Park, CA: Benjamin/Cummings.

Weinberger, D. R. (1987). Implications of normal brain development for the pathogenesis of schizophrenia. Archives of General Psychiatry, 44, 660669.

Weiss, P. (1969). Principles of development. New York: Hafner.

Werner, H. (1948). Comparative psychology of mental development. New York: International Universities Press.

Westen, D. (in press). Toward a revised theory of borderline object relations: Implications of empirical research. International Journal of Psychoanalysis.

Zimmerman, R. A., Bilaniuk, L. T., \& Grossman, R. I. (1983). Computed tomography in migratory disorders of human brain development. Neuroradiology, 25, 257-263. 


\section{FIFTH ANNUAL ROCHESTER SYMPOSIUM ON DEVELOPMENTAL PSYCHOPATHOLOGY OCTOBER 3-5, 1991}

The fifth annual Rochester Symposium on Developmental Psychopathology, sponsored by Dante Cicchetti, will be held on October 3-5, 1991, in Rochester, NY. This year's symposium will focus on the self and its disorders.

For information and registration materials contact:

Donna Bowman

Mt. Hope Family Center

187 Edinburgh Street

Rochester, NY 14608

(716) 275-2991 